\title{
UBIQUITOUS MICROBES AND ECOSYSTEM FUNCTION
}

\author{
B.J. Finlay* \& G.F. Esteban \\ Centre for Ecology and Hydrology, Windermere Laboratory, The Ferry House, Far \\ Sawrey, Ambleside, Cumbria LA22 OLP, United Kingdom. bjf@ceh.ac.uk \\ *Corresponding author
}

\begin{abstract}
Until recently, microbial diversity was the least well understood component of biodiversity. But free-living microbes have some unique characteristics, and it is now believed that these may simplify the task of understanding biodiversity at the microbial level. Microbes have astronomical abundance on a global scale. As a consequence, species are ubiquitous, so speciation and extinction are rare, the global number of microbial species is relatively small, and local species richness is a large proportion of global species richness. At some critical point on the continuum of increasing organism size, local:global species richness ratios will begin to decrease and the proportion of the world's taxa represented at a single site will begin to fall. The organism size range marking this "ubiquity-biogeography '(U-B) transition is unknown but is unlikely to extend below I $\mathrm{mm}$. As "everything (microbial) is everywhere", ecosystem functions will rarely, if ever, be limited by lack of microbial diversity.
\end{abstract}

Keywords: biodiversity, ciliates, geographic distribution, protozoa, ubiquity

\section{RESUMEN}

Hasta muy recientemente, la diversidad microbiana ha sido el área peor comprendida de la biodiversidad. Sin embargo, debido a que los microorganismos de vida libre presentan caracteristicas incomparables, es ahora cuando se cree que dichas caracteristicas puede que aclaren la comprension de la biodiversidad en términos microbianos. Los microorganismos tienen abundancias astronomicas a escala mundial. Como consecuencia de esta abundancia, las especies son ubicuas y, por tanto, la evolucidn especifica y la extincidn son raras; el numero mundial de especies microbianas es relativamente pequeño; y la riqueza de especies a nivel local es una proporción grande de la riqueza de especies a nivel mundial. La continuidad en el incremento de tamafio de los organismos debe presentar un punto critico en el cual la proporción de la riqueza de especies local:mundial debe empezar a disminuir; punto critico también a partir del cual la proporcidn de los taxones del mundo que se pueden encontrar en un sitio determinado, empieza a caer. La escala de tamafio en la transición "ubicuidad-biogeografia" (U-B) no se conoce pero muy probablemente no se extienda por debajo de $1 \mathrm{~mm}$. Como a nivel microbiano "todo está por todas partes", las funciones propias del ecosistema van a verse muy raramente limitadas por una falta de variedad microbiana.

Palabras clave: biodiversidad, ciliados, distribución geografica, protozoos, ubicuidad

\section{INTRODUCTION}

Microbes are fundamentally different from animals and plants. The most obvious difference is in size, for a typical microbe has a biomass many orders of magnitude smaller than any macroscopic organism. But another, equally important character of microbes is also derived from small body size - extraordinarily large abundance. Natural aquatic communities tend to support roughly similar biomass in each logarithmic size class (Sheldon et al., 1972; Fenchel, 1987a), so the number of individuals in each class will be inversely proportional to size. Thus we expect much greater numbers of bacteria and protozoa, than of larger organisms such as zooplankton and fish. This of course is what is found - and in the case of microbes, population sizes in the natural environment are, in relative terms, astronomically large. It is, for example rather difficult to find a sample of freshwater that contains fewer than $10^{6}$ bacteria or 1000 flagellated protozoa per mil- 
liliter (Berninger et al., 1991), and abundance in sediments is even higher.

Great abundance has important implications for natural dispersal, because it raises the possibility that representatives of each species may, for purely statistical reasons, be frequently transported even over large distances. Microbial species may, in fact, be ubiquitous. Like fish (Gislén, 1948) and iguanas (Censky et al., 1998), microbes will be picked up by typhoons, or transported hundreds of kilometers by hurricanes. They may be carried on the feet and damp feathers of ducks and other migratory birds (Darwin, 1859), or, like pollen grains (Campbell et al., 1999), fungal spores (Marshall, 1996), and even insects (Felt, 1926), be carried in wind or convection currents high into the atmosphere and transported thousands of kilometers. Less dramatically, microbes will be transported in ground waters and in innumerable other ways. The important point is that with extremely large numbers of individuals involved, the statis- tical probability of some proportion of a species being transported with high frequency to other places in the biosphere, is relatively high. This is vividly illustrated by Roberts \& Cohan (1995), who estimated the rate of migration between populations of a soil bacterial species to be sufficiently high to limit the accumulation of neutral genetic divergence, whatever the geographic scale. Indeed it was estimated that during the timespan of a single bacterial generation, more than one viable cell on average is transported between populations on different continents. A macroscopic organism such as a fish may, because it lives a long time and has innate migratory behaviour, be more likely than an individual microbe of migrating from one pond to a neighbouring pond, but in the same period of time, the vast numbers of individuals in any microbial species will ensure that some representatives of the species are frequently transported over great distances, and significantly, across the geographic barriers (e.g. mountain

Figure 1. Some examples of the morphological and functional diversity of protozoa. A) The flagellate Paraphysomonas butcheri after shadowing with Au-Pd for electron microscopy (photo courtesy of K.J. Clarke, CEH-Windermere). The cell bears two flagella, the longer $5 \mu \mathrm{m}$ long, and the cell is covered with siliceous scales of two types (arrowheads). B) The freshwater ciliate Euplotes daidaleos in lateral view (ca $90 \mu \mathrm{m}$ in length), crawling on a sediment particle. Arrowheads point to the cirri ("walking" groups of cilia) that function as tiny appendages. The dark cytoplasm is due to the chlorophyll of endosymbiotic Chlorella (see also G.) C) The planktonic ciliated protozoon Prorodon viridis after silver-impregnation (cell length ca $85 \mu \mathrm{m}$ ). Note the ciliary rows formed by the basal bodies of the cilia. Ch, endosymbiotic Chlorella (seen here as dark particles in the cytoplasm); N, macronucleus (grey circle in the cytoplasm); OA, oral aperture. D) Living specimen of the common peritrich ciliate Vorticella, with a contracted stalk. Phase contrast. E) The suctorian ciliate Podophrya attached to the surface of another ciliate, Nassula aurea. Suctorians lack cilia and oral structures, but have specialised feeding tentacles (arrowheads to some of them). (D and E courtesy of Dr H Canter-Lund, Freshwater Biological Association, Ambleside). F) A specimen of the amoeba Platyamoeba sp. isolated from soil. Arrowhead to a recently engulfed bacterium. G) Endosymbiotic Chlorella in the cytoplasm of Euplotes daidaleos. Note the individual cilia that form the cirri (arrowheads). Nomarski Interference contrast. Ch, endosymbotic Chlorella; $\mathrm{B}$, a 16-cell colony of the anaerobic purple photosynthetic bacterium Thiopedia sp. co-existing with E. daidaleos; the photosynthesing endosymbionts in E. daidaleos create an oxygenated cytoplasm in the ciliate, allowing it to retain an aerobic metabolism even when the ciliate is surrounded by anoxic water (Finlay et al., 1996c). Algunos ejemplos de la diversidad morfológica y funcional de los protozoos. A) El flagelado Paraphysomonas butcheri después de un sombreado con Au-Pd para la observación al microscopio electrónico (foto cortesía de K.J. Clarke, CEH-Windermere). La célula está provista de dos flagelos, el más largo de $5 \mu \mathrm{m}$ y la célula esta cubierta con escamas silícicas de dos tipos (indicados por flechas). B) El ciliado de agua dulce Euplotes daidaleos en visión lateral (ca $90 \mu \mathrm{m}$ de largo), reptando sobre un partícula de sedimento. Las flechas señalan a los cirros (grupos de cilios "andadores") que funcionan como minúsculos apéndices. El citoplasma oscuro se debe a la clorofila de Chlorella endosimbiontes (ver también $G$ ) C)El ciliado planctónico Prorodon viridis después de una impregnación con plata (longitud de la célula ca 85 um) Obsérvese las filas formadas por los cuerpos basales de los cilios. Ch. Chlorella endosimbiontes (vistas aqui como particulas oscuras en el citoplasma); $N$, macronúcleo (círculo gris en el citoplasma); OA, apertura oral. D) Individuo vivo del ciliado peritrico Vorticella, con el pedúnculo contraido. Contraste de fases. E) El ciliado suctor Podophrya enganchado a la superficie de otro ciliado, Nassula aurea. A los suctores les faltan los cilios y las estructuras orales, pero tienen tentáculos especializados en la alimentación (las flechas indican algunos de ellos) (D $E$ cortesia de la Dra. H. Canter-Lund. Freshwater Biological Association, Ambleside). F) Un espécimen de la ameba Platyamoeba sp. aislada del suelo. La flecha indica una bacteria recientemente ingerida. G) Chlorella endosimbionte en el citoplasma de Euplotes daidaleos Obsérvense los cilios individuales que constituyen el cirro (flechas). Contraste interferencial de Nomarski. Ch, Chlorella endosimbionte; $B$, una colonia de 16 células de la bacteria anaeróbica fotosintética purpúrea Thiopedia sp. coexistiendo con $\mathrm{E}$. daidaleos; los endosimbiontes fotosintéticos en $\mathrm{E}$. daidaleos crean un citoplasma oxigenado en el ciliado, permitiéndole mantener un metabolismo aeróbico incluso cuando el ciliado está rodeado de agua anóxica (Finlay et al., 1996c). 


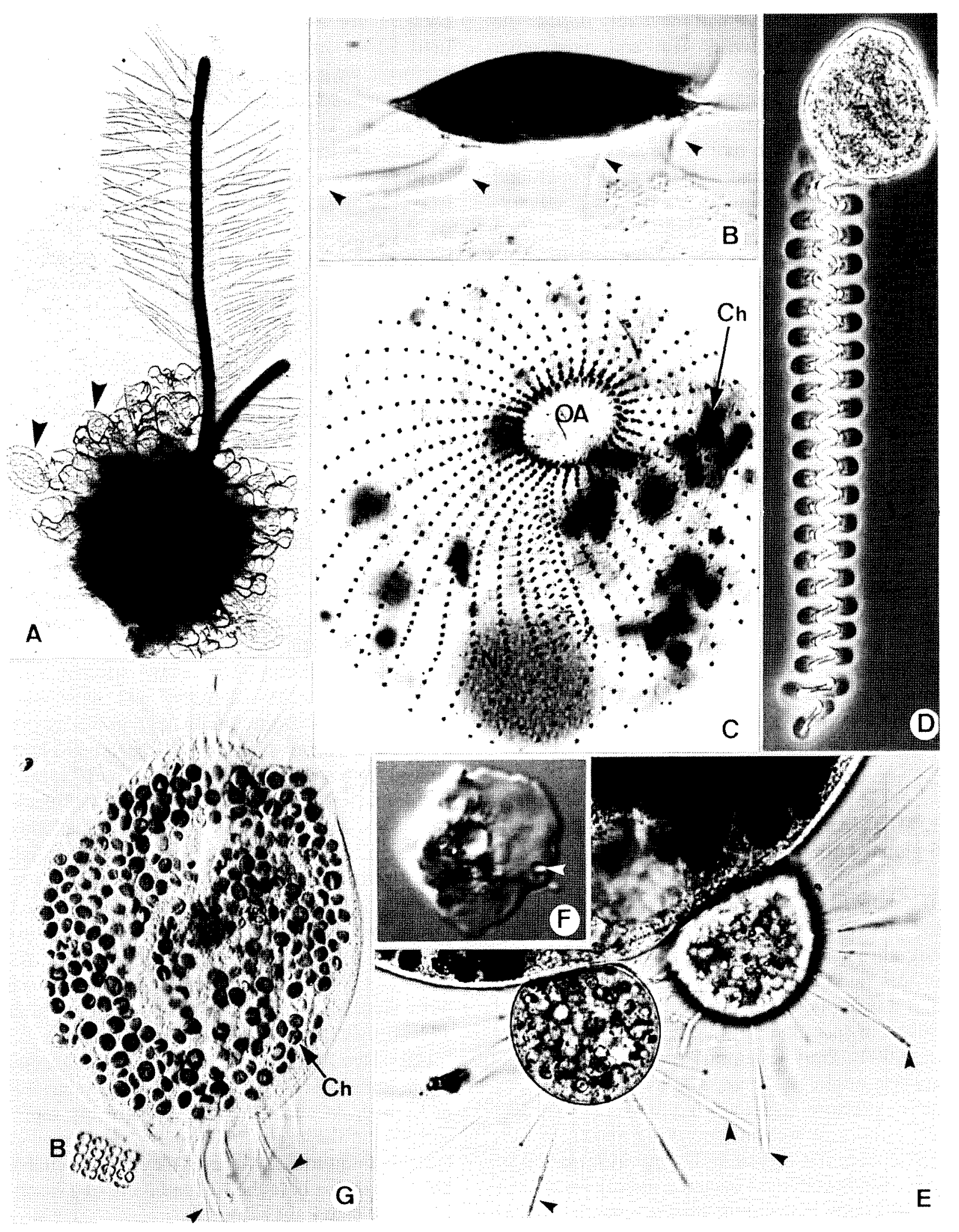


ranges, sea water) that will inevitably impede the progress of a freshwater fish and most other macroscopic organisms.

Here, we focus mainly on microbial eukaryotes. There are two reasons for doing so. The first is that we avoid the more intractable arguments about the nature and definition of microbial species. Species definitions of microbial eukaryotes are by no means unambiguous and free from controversy (Finlay et al., 1996a) but in some groups, such as the protozoa, and the ciliated protozoa in particular, there are well-defined morphospecies with conservative features, and obvious correlation of form and function (Fig. 1). For example, the size and shape of a protozoon, together with the presence or absence of endosymbionts, method of feeding and structure of feeding apparatus, tell a lot about the ecological niche that the organism occupies.

Second, protozoa are especially relevant because they are among the largest of microorganisms. Bigger micro-organisms are less abundant than small ones, so if it can be shown that big microbial species are ubiquitous, it is good evidence that the smaller, considerably more abundant microbial species, are ubiquitous also.

The argument expressed in this article can be explained in four sequential steps, as follows:

\section{Microbes have astronomical abundance on a global scale}

The numerical density of a species increases with the inverse of body mass (Peters, 1983). For all large groups of animals it appears that the slope of this relationship is always approximately -1 , and this applies over a size range of at least 20 orders of magnitude (Marquet, 2000; Schmid et $a l ., 2000)$. Thus a mammal species of intermediate size might be represented by about $10^{-5} \mathrm{~m}^{-2}$, an invertebrate species living in a stream by $10^{-1}$ $\mathrm{m}^{-2}$, and a protozoan species by about $10^{5} \mathrm{~m}^{-2}$. There does not appear to be any information of this type available for bacteria, mainly because of the difficulty in deciding what is a species, but as bacteria are about 1000 times more abundant (and 1000x smaller in mass) than the smallest protozoa, we can assume that the relation extends downwards for at least a further three orders of magnitude. The protozoan data shown (Fig. 2) include a wide range of functional types from freshwater (Finlay \& Esteban, 1998a) and terrestrial (Finlay et al., 2000) environments collected by the authors and colleagues. There are some obvious gaps in the data but it looks as if a more comprehensive protozoan dataset will fill out a large ellipse centred on an abundance of approximately $10^{6} \mathrm{~m}^{-2}$.

\section{Most if not all microbial species are global- ly ubiquitous}

\section{Australian ciliates}

Finlay et al. (1999) and Esteban et al. (2000) investigated the ciliated protozoa in a habitat that is separated from Northern Europe by geographical barriers and great distance - the sediment of a Holocene volcanic crater-lake with brackish water, in Australia. Eighty-five ciliate species were recorded, but none was 'new' and most were already known from Northern Europe by the 1930s. The ciliates in the crater appeared to have arrived from a variety of habitats - thus 10 species were typical of soil, 54 of fresh waters, 8 of brackish waters, and 13 of marine waters. Remarkably, the large and fragile marine interstitial ciliate Tracheloruphis caudata was also found. It presumably arrived in the crater from the Southern Ocean, which is curious as this species is not known to form a protective cyst. Remarkably, AIRasheid (1996) too, has found this species and other similarly fragile 'marine' species, in oases with slightly salty water in the Arabian desert.

All of the Australian crater-lake ciliate species are morphologically identical to species that live in Europe. As such, they are presumably representative of the large number of microbial species that are ubiquitous. Wherever they find a suitable habitat - in this case the soft sediment of a brackish-water lake - they flourish. 


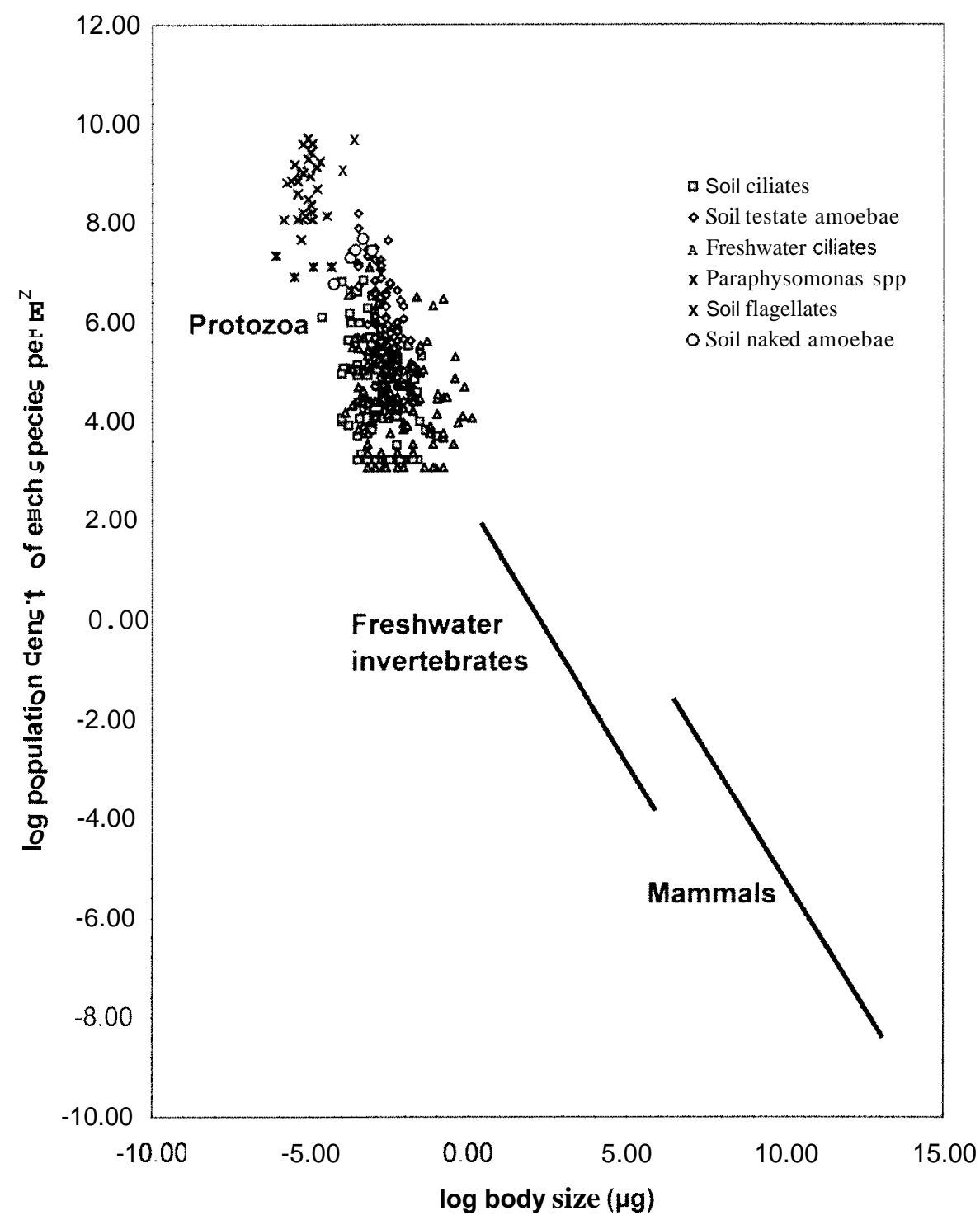

Figure 2. The numerical density of species increases with the inverse of body mass (Peters, 1983). Here, our collected data for protozoa have been superimposed as an extension of the data for metazoans (see Marquet, 2000; Schmid et al., 2000) to emphasise the extraordinary abundance (up to about $10^{9} \mathrm{~m}^{-2}$ ) of the smallest 'animal-like' organisms. For all taxonomic groups, the slope of the relationship appears to be about -1. La densidad numérica de especies se incrementa con la inversa de su masa corporal (Peters, 1983). Aquí, nuestros datos para protozoos han sido añadidos como una extensión de los datos para los metazoos (ver Marquet, 2000; Schmid et al., 2000) para enfatizar la extraordinaria abundancia (superior a $10^{4} \mathrm{~m}^{-2}$ ) de los organismos más pequeños 'pnrecidos a animales'. Para todos los grupos taxonómicos, la pendiente de la relación parece esta alrededor de -1 .

\section{Paraphysomonas}

The flagellated protozoa in this genus have species-specific scale types, and forty-one species have been recorded in published surveys covering all continents. We recently removed a very small sample $\left(<0.1 \mathrm{~cm}^{2}\right)$ of superficial sediment from a productive freshwater pond (Finlay \& Clarke, 1999a,b), and spent several months examining it with transmission electron 
microscopy, looking for scales and cell parts of Paraphysomonas. As we had previously determined the number of scales required to make a whole cell of each species, we could then calculate the abundance of each species in the pond sediment. We found remains of 32 of the 41 species (i.e. 78\%) recorded in surveys carried out around the world. Furthermore, it was found that species that are globally rare or abundant are likewise rare or abundant in the pond. Thus $P$. vestita and P. imperforata - species found in almost all samples worldwide, are also the most abundant species in the pond; whereas $P$ planus and $P$. runciniferopsis, present in less than $1 \%$ of samples worldwide, are among the least abundant species in the pond. One explanation is as follows. Species such as $P$. imperforata that can live in a broad range of conditions (everything from almost distilled water to $2.6 \mathrm{x}$ full strength sea water [Lee, 19781) will thrive in a wide range of natural environments, and global abundance will be high. This will drive a high rate of dispersal, and raise the probability that newly-created habitats are colonised at an early stage by what is in effect a protozoan 'weed'. Thus species that are globally abundant, will also be locally abundant. In contrast, a species such as I planus, which may be more discriminating in its requirements is thereby much rarer, globally and locally, yet still able to find its specific niche in the pond environment.

\section{Cryptic species within morphoespecies}

The obvious link between form and function in many microbial eukaryotes and microfauna means that there is at least some consensus on what a morphospecies is for these groups. However, it is recognised that most if not all microbial eukaryote morphospecies probably harbour further layers of diversity - whether genetically fixed physiological variants (e.g. differing with respect to the range of temperature or salinity in which growth and survival are possible [see Fenchel, 1987b]), or genetic variation, which may be uncoupled from function and fitness (e.g. rDNA or ribosomal ITS [Bowers et al., 1998;
Coleman et al., 1994; Larsen \& Medlin, 1997; Kusch, 1998; Wright, 1999]), but which reflects phylogenetic relationships between constituent organisms. For example, the morphospecies Paraphysomonas imperforata may include different physiological strains. Choi \& Peters (1992) showed that isolates from different latitudes had different genetically-fixed optimum temperatures at which growth rate was maximal. The same phenomenon was documented by Lee \& Fenchel (1972) for ciliates. The picture that emerges then is of morphologically identical individuals filling out what appears to be a continuum of slightly differing genotypes, each of which may or may not be ubiquitous (but this is not yet known).

With respect to genetic (ribosomal DNA base sequence) variation within morphospecies, there is no evidence that this is correlated with geography. Kusch (1998) carried out genotypic characterisation of the very large ciliate Stentor coeruleus found in ponds in Germany. He found sequence variation, but genetic distance was not correlated with geographic distance. Ciliates in neighbouring ponds or in water bodies separated by hundreds of kilometers could, in each case, have genetic sequences that are either identical, or quite different. And Atkins et al. (2000) have shown that flagellates associated with hydrothermal vents separated by thousands of kilometers in the Pacific can be genetically identical to each other and to specimens isolated from surface waters in Northern Europe.

\section{As there are no effective barriers to disper- sal, speciation will be rare, so the global num- ber of microbial species will be relatively small, and local species richness will be a large proportion of global species richness.}

\section{Global number of species}

There is no universal agreement on what constitutes a 'species' of protozoon or almost any other type of microbial eukaryote. The most widely used concept is the morphospecies, but this often contains genetic and physiological variants which 
are occasionally referred to as separate species. And there is also at least one other complicating factor - namely 'sex'. Protozoa probably spend most of their existence as asexual organisms, but some do reproduce sexually, if only periodically, and in some well-studied cases, morphologicallyindistinguishable biological species (i.e. reproductively isolated gene pools, also known as sibling species) have been studied thoroughly (Nanney, 1999). Much is known about the genetics of these, but relatively little is known about their ecological differences, if any. Sibling species may carry specific phenotypic traits, but this has not been demonstrated (Nanney et al., 1998). The same sibling species can be found on different continents and there is no firm evidence that any of them has biogeography. The real problem of using a biological species concept for protozoa is that it is so impractical. Most protozoan species have never been cultivated, and neither the frequency nor character of their sexual behaviour (if any) is known, or is likely ever to be known. Most people who study protozoa in the natural environment use the morphospecies concept because it is practical, because it embodies the close link between form and function, and because it is the morphospecies that appears to fill the niche, if not always the minutest niches that are perceived by protozoa. The morphospecies may contain genetic (rRNA) variants, phenotypic variants (differing in response to temperature and salinity, e.g. Pérez-Uz, 1995), and genetically isolated populations (sibling species) but the accumulated evidence indicates that the morphospecies and their constitutent parts have widespread, and probably global, distributions. Thus the evidence at present indicates that morphospecies and their constituent genetic and physiological variants, may be ubiquitous.

Various estimates have been made of the global number of protozoan morphospecies. The term Protozoa does of course include a very diverse collection of organisms, so it is necessary to specify the taxonomic coverage we are dealing with. For our present purpose, one workable definition of 'protozoa' is 'free-living phagotrophic microbial eukaryotes'. Corliss (1999, and pers. comm.) estimated the number in this group by honing down his total $(83,000$ species $)$ for all protozoa. He removed 51,000 fossil forms, 10,000 symbiotic/parasitic species, and 3,000 pigmented non-heterotrophic euglenids and dinoflagellates, to produce a total of 19,000 freeliving phagotrophic species. From a completely independent analysis of published and unpublished sources, Finlay (2000) too estimated global (morpho)species richness of extant freeliving protozoa as follows:

$\begin{array}{lr}\text { Amoeboid protozoa } & 6570 \\ \text { Flagellated protozoa } & 2260 \\ \text { Ciliated protozoa } & 3060 \\ \text { Total } & 11890\end{array}$

It is rather difficult to obtain reliable data of this type for the protozoa, so it is remarkable that the independent estimates from Corliss and Finlay $(19,000$ and 12,000 respectively) are as close as they are. The biggest problems are associated with the biggest taxonomic groups. For example, in the amoeboid protozoa, the benthic foraminiferans are represented by roughly 4000 nominal species, but it is generally accepted that this number is grossly inflated by synonyms - especially in the shallowwater benthic species. It is unlikely that estimates of global (morpho) species richness will increase greatly in the future if as much effort is given to taxonomic revisions and the removal of synonyms, as to describing new species. Thus we may conclude that the global number of protozoan morphospecies is relatively low and is unlikely ever to approach the species richness typified by those higher taxa whose species do, typically, have biogeographies (e.g. the insects, represented by roughly 5 million species; Gaston, 1992).

\section{Local:global species ratios}

The term 'local' means different things to different people. Even if it appears to refer to something as specific as a discrete one-hectare pond, it is still impossible to investigate the whole pond and in reality only a tiny proportion will be exa- 
mined. Nevertheless, in such a pond in England (Priest Pot) more than 25\% (i.e. $>270$ spp.; Finlay et al., 1998; Finlay \& Maberly, 2000) of the global number of ciliate species have been found so far. But even this may be an underestimate, because many ciliate species are typically rare or cryptic and not easily detected. To test this, a small sample of sediment (a single Jenkin core internal area $36 \mathrm{~cm}^{2}$ ) was taken from Priest Pot and the top $1 \mathrm{~cm}$ was manipulated (exposed to various temperatures, redox gradients, food sources, light regimes, etc.) to produce a variety of niches to support a range of species (Finlay et al, 1996b; Fenchel et al, 1997). These procedures created conditions suitable for population growth by a previously hidden 'seedbank' of species. At the beginning of the experiment 20 species were active and detectable in the surface sediment of the core. Subsequent manipulations over a threemonth period raised this number to 135 species.

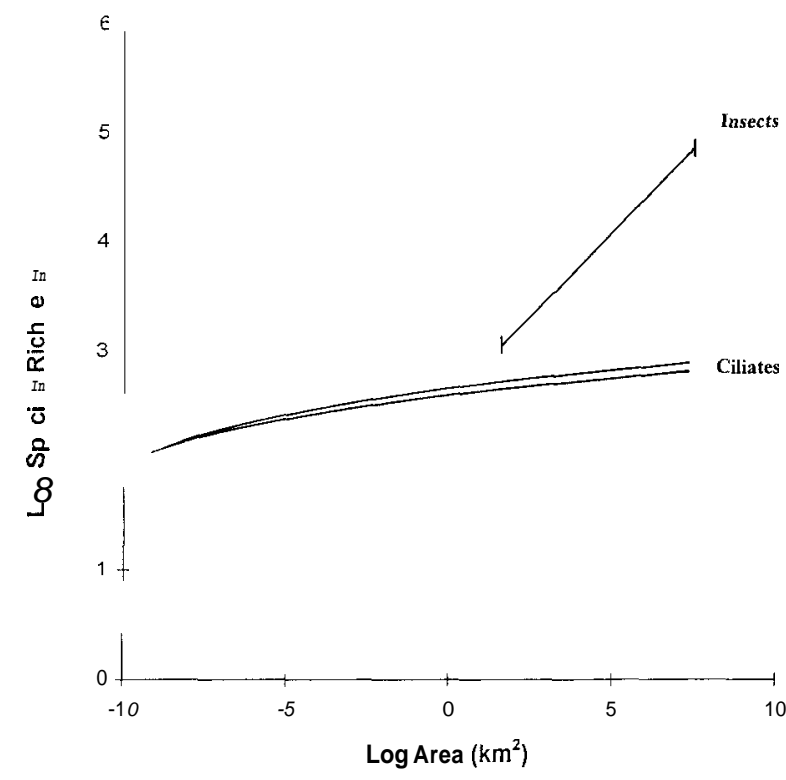

Figure 3. Species-area relationships for freshwater benthic and marine interstitial ciliates (upper and lower curves respectively). The regression drawn for the insects uses the data for various regions of the world assimilated by Gaston (1992). Modified after Finlay et al. (1998). Reluciones especies-área puru ciliados bento'nicos de uguu dulce e intersticiules marinos (curva superior e inferior respectivumente), La regresión dibujadu puru los insectos usa los dutos de varias regiones del mundo recogidas por Gaston (1992). Modificado de Findlay et al. (1998).
The local : global species ratio for microbial eukaryotes can apparently be very high. It can be placed in perspective by comparing the speciesarea curve for free-living ciliates with that for insects (Fig. 3) - a group in which many species do, undoubtedly, have biogeographies. The curves for ciliates are remarkably flat and the majority of their global species richness can be found in a relatively small area.

\section{Ubiquity-Biogeography transition.}

At some critical point on the continuum of increasing organism size, local : global species richness ratios are expected to decrease and the

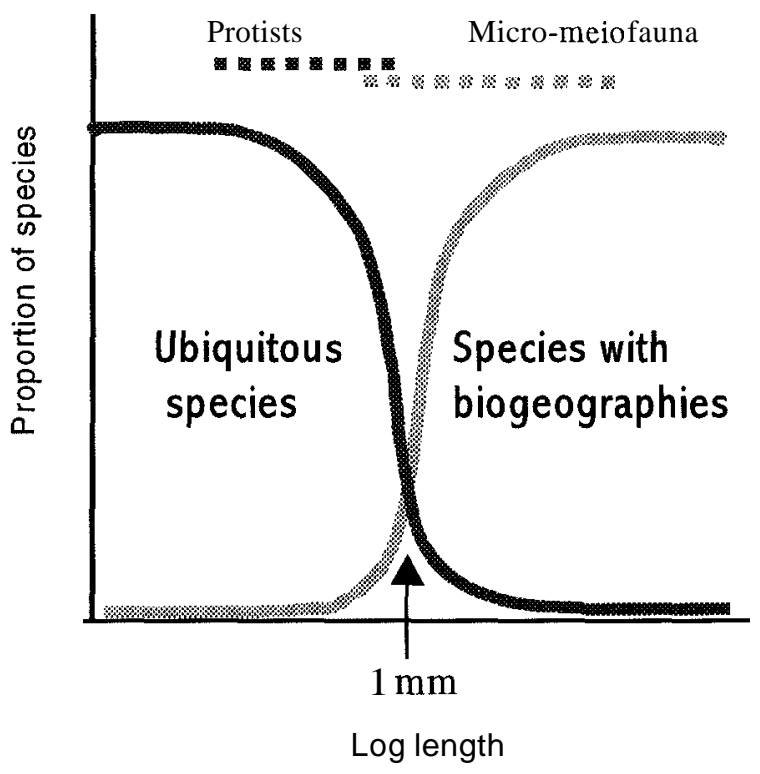

Figure 4. The prediction is that with increasing body size of species, the proportion of species that are ubiquitous will fall, and the proportion with biogeographies will increase. Thus all bacterial species are expected to be ubiquitous, whereas all large mammal species are expected to have biogeographies. The location of the ubiquity-biogeography (U-B) transition, is still unknown, but unlikely to extend below $1 \mathrm{~mm}$. Lu predicción es que con el incremento del tamaño del cuerpo de las especies, la proporción de especies uhicuas bajará, y la proporción con distribución biogeográfica limitada aumentará. Así se espera que todas las especies de hucterias sean ubicuas, mientrus que se esperu que todas las especies de grundes mamíferos tengan unu distrihucidn biogeograficu restringidu. La posición del punto de trunsicidn ubicuidad-distribución biogeográfica limitada (U-8) es aún desconocida, aunque dificil de extender por debajo de I $\mathrm{mm}$. 
proportion of the world's taxa represented at a single site will begin to fall. The location of this region, which we here refer to as the ubiquitybiogeography (U-B) transition, is unknown, although it is believed (Lawton, 1998) to be in the region of $1 \mathrm{~mm}$ (see Fig. 4). One objective for the future will be to identify the taxa, and define the organism size range, that span the U-B transition.

\section{Are there any microbial endemics?}

Most (if not all) microbial eukaryotes will be on the ubiquity side of the U-B transition but there remains the possibility that some endemics do exist. Free-living microbial eukaryotes appear not to have biogeographies but a case for restricted distribution could, perhaps, be made for some very large ciliate species (Fenchel, 1993), for these are considerably less abundant than small species (Finlay et al., 1999). In recent years there has been a serious attempt to find large microbial eukaryotes that might be endemics - so far without success. Even the largest of ciliates, such as Loxodes rex (Dragesco, 1970) - previously believed to be endemic to tropical Africa, has recently been found in Thailand (Esteban et al. 2001). We remain unconvinced that there is a single example of an endemic protist species. Some species may appear to be endemic - e.g. the unusual desmid species from Tasmania (Tyler, 1986). But another possible explanation is that unusual (and locally restricted) habitats - created perhaps by unusual endemic plants - provide local microhabitats for specific types of microorganisms. Thus the unusual desmids may still be dispersed over large areas - they may even be ubiquitous - but remain rare and undiscovered outside of their places of origin, because of the global scarcity of suitable habitat.

\section{Species richness is afunction of sampling effort.}

It is likely that undersampling has been a serious problem contributing to underestimates of local species richness and to the unjustified erection of species as endemics. One clear example of the value of increased sampling effort is provided by

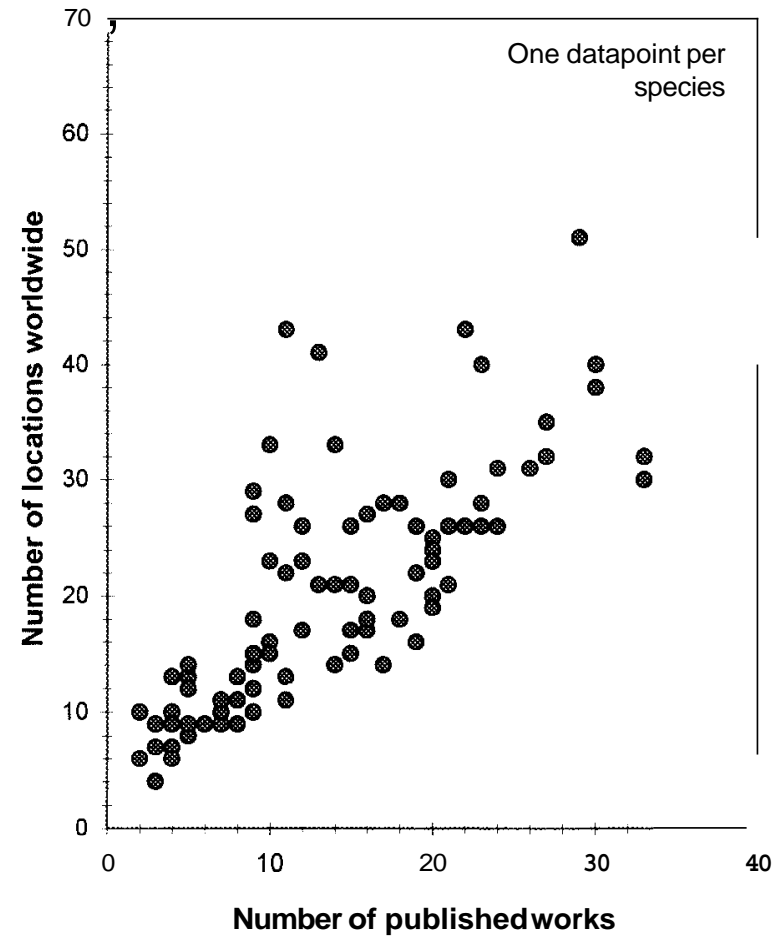

Figure 5. Ogden \& Hedley (1980) provided notes on the geographical distribution of 95 species of freshwater testate amoebae. The authors included data for (a) the number of published works referring to each species. and (b) the number of locations worldwide where each species had been found. It is apparent that the more often a testate species is recorded (this presumably being correlated with its global commonness), the wider does its apparent geographical distribution become. This suggests that the ubiquity model is appropriate, and that additional sampling at any site will reveal more (or all) of the rarer species. Ogden y Hedley (I980) proporcionaron datos sobre la distribución geográfica de 95 especies de amebas tecadas de agua dulce. Los autores incluyeron informacidn de (a) el número de trabajos publicados que se referia a cada rspecie, y $(b)$ el número de localidades de todo el mundo donde cada rspecie había sido hallada. Se puede observar que cuunto más frecuente es citadu una rspecie tecada (esto está presutnihlemente correlacionado con su abundancia global), mas amplia se vuelve su distribución geográfica aparente. Esto sugiere que el modelo de ubicuidad es apropiado, y que los muestreos adicionales en cualquier localidad revrlurun más (o todas) de las especies raras.

the testate amoebae, where it is shown that the more often a testate species is recorded, the wider does its apparent distribution become (Fig. 5). If any of these species had been endemics they would have fallen into the bottom right of the figure, and this clearly is not so. 


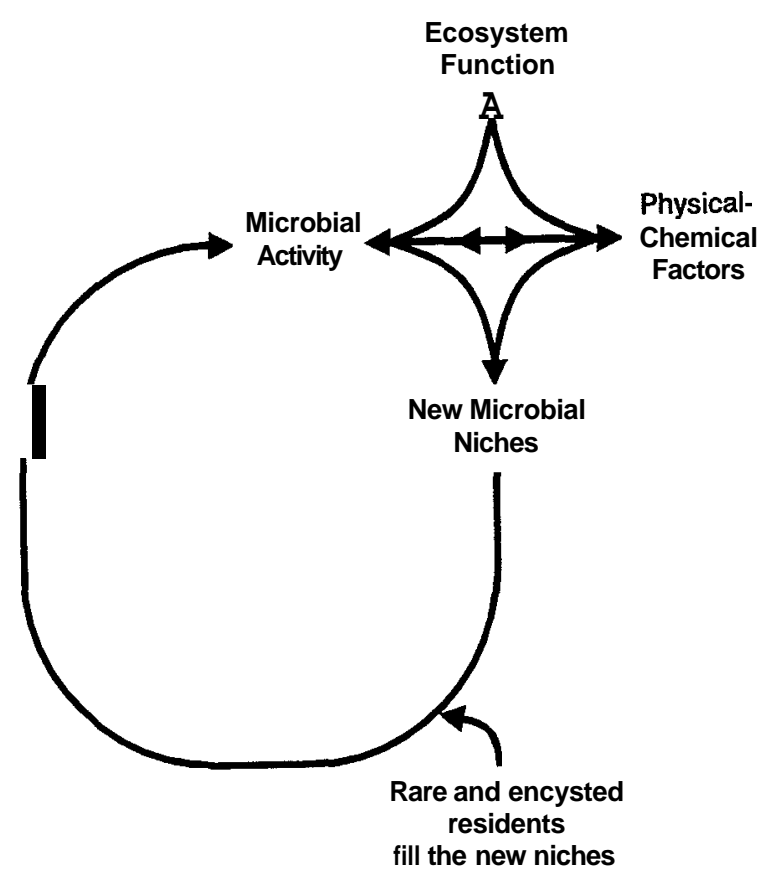

Figure 6. Microbial activity and diversity are inextricably embedded in ecosystem functions such as carbon fixation and decomposition, and nutrient cycling. There is continuous interaction between microbial activities (e.g. oxygen consumption, nitrogen excretion) and physical-chemical factors (e.g. water temperature, sub-surface light penetration, concentrations of dissolved oxygen and nutrients). These interactions create a continuous turnover of microbial niches, which are immediately filled from the seedbank of rare or cryptic species, especially those 'waiting' in the sediment. Thus the active microbial biodiversity is a dynamic quantity. On the one hand it is the consequence of previous interplay between biological and nonbiological factors and the types of microbial niches provided from these interactions. On the other hand, the active microbial biodiversity is what determines how the ecosystem functions at that moment in time. Modified from Finlay et al., 1997. Actividad y diversidad microbiana están inextricablemente encajados en funciones del ecosistema tales como lafijacion de carbono y la descomposición, y el ciclo de los nutrientes. Hay una continua interacción entre actividades microhianas (p.e. consumo de oxigeno, excreción de nitrógeno) y factores físico-químicos (p.e. temperatura del agua, penetración subsuperficial de la luz, concentraciones de oxigeno disuelto y nutrientes). Estas interacciones crean un cumhio continuo de los nichos microbianos, que son inmediatamente ocupados a partir del hanco de semillas de especies raras o crípticas, especialmente de aquellas que están "aguardando" en el sedimento. A si la diversidad microhianu activa es una cantidad dinamica. Por un lado es una consecuencia de la interelucidn previa entre factores hioldgicos y no biologicos y los tipos de nichos microhianos producidos por estas interucciones. Por otro ludo, la diversidad microhiana activa es la que determina cdmo el ecosistema funciona en cada momento. Modificado de Finlay et al., 1997.

\section{As everything (microbial) is everywhere, ecosystem functions will rarely be limited by lack of microbial diversity.}

Ubiquitous dispersal of microbial species means that each ecosystem will contain a large 'seedbank' of microbial species that are imported by random dispersal and which will not normally thrive in that particular ecosystem. Rather, they persist as spores, cysts, or relatively rare trophs waiting for suitable conditions to arrive. The full potential of this seedbank has never been explored, although analysis of specific taxonomic groups (e.g. ciliates, see above) indicates that it may be very large. This seedbank may be crucially important in allowing the ecosystem to respond to perturbation, and continue to function. This is illustrated in the dynamic reciprocal interactions between microbial, physical and chemical factors in temperate freshwater lakes (e.g. Finlay et al., 1997). For example, seasonal warming and stratification of the water column leads to enhanced microbial activity, deoxygenation of the bottom water and sediment, and creation of a niche for nitrate respirers, which quickly become abundant. When nitrate is exhausted, sulphate reducers produce hydrogen sulphide, and a niche is created in anoxic water for photosynthetic bacteria, which grow to form a thick layer just above the sediment, preventing the upwards diffusion of inorganic nitrogen. These in turn support population growth of anaerobic protozoan grazers. In autumn, the physical factors of wind and surface cooling cause ammonia to be lifted up into oxygenated water, thus a niche is created for nitrifiers that supply oxidised nitrogen to the upper water. These are just a few examples of reciprocal interactions driving the creation of microbial niches which are then quickly filled from the seedbank of waiting microbes. In any natural ecosystem, the real complexity of interactions between hundreds of species and dozens of ecosystem processes is unimaginably large. But the net result of all physical-chemical-microbial interactions is the way the ecosystem functions, and it is apparent that microbial activity and diversity are both inextricably and dynamically linked with 
ecosystem function (Fig. 6). The ciliate species living in a pond are probably like any other microbial group in the plankton (Fig. 7) - none of which ever achieves anything resembling equilibrium abundance. They 'appear' and 'disappear' at fairly irregular intervals in response to the generation of a continuous turnover of microbial niches.

\section{ACKNOWLEDGEMENTS}

We are greatly indebted to Prof. E. Vicente and Prof. M.R. Miracle for the invitation to attend the Valencia Congress and the opportunity to witness at first hand, the breadth and vigour of limnological studies in Spain. This work was supported financially by the Natural Environment Research Council (UK), throug the Soil Biodiversity Thematic Programme (Grant n ${ }^{\circ}$ GST 2130).

\section{REFERENCES}

AL-RASHEID, K.A.S. 1996. Records of free-living ciliates in Saudi Arabia. II. Freshwater benthic ciliates of Al-Hassa Oasis, Eastern Region. Arab Gulf J. Scient. Res., 15: 187-205.

ATKINS, M.S., A.P. TESKE, \& O.R. ANDERSON. 2000. A survey of flagellate diversity at four deepsea hydrothermal vents in the Eastern Pacific Ocean using structural and molecular approaches. J. Eukuryot. Microbiol., 47: 400-411.

BERNINGER, U.G., B.J. FINLAY, \& P. KUUPPOLEINIKKI, 1991. Protozoan control of bacterial abundsances in fresh waters. Limnol. Oceanogr., 36: 139-147.

BOWERS, N., T.T. KROLL, \& J.R. PRATT, 1998. Diversity and geographic distribution of riboprints from three cosmopolitan species of Colpoda Müller (Ciliophora: Colpodea).Europ. J. Protistol., 34: 341-347.

CAMPBELL, I.D., K. MCDONALD, M.D. FLANNIGAN, \& J. KRINGAYARK, 1999. Long-distance transport of pollen into the Arctic. Nature, 399: 29-30.

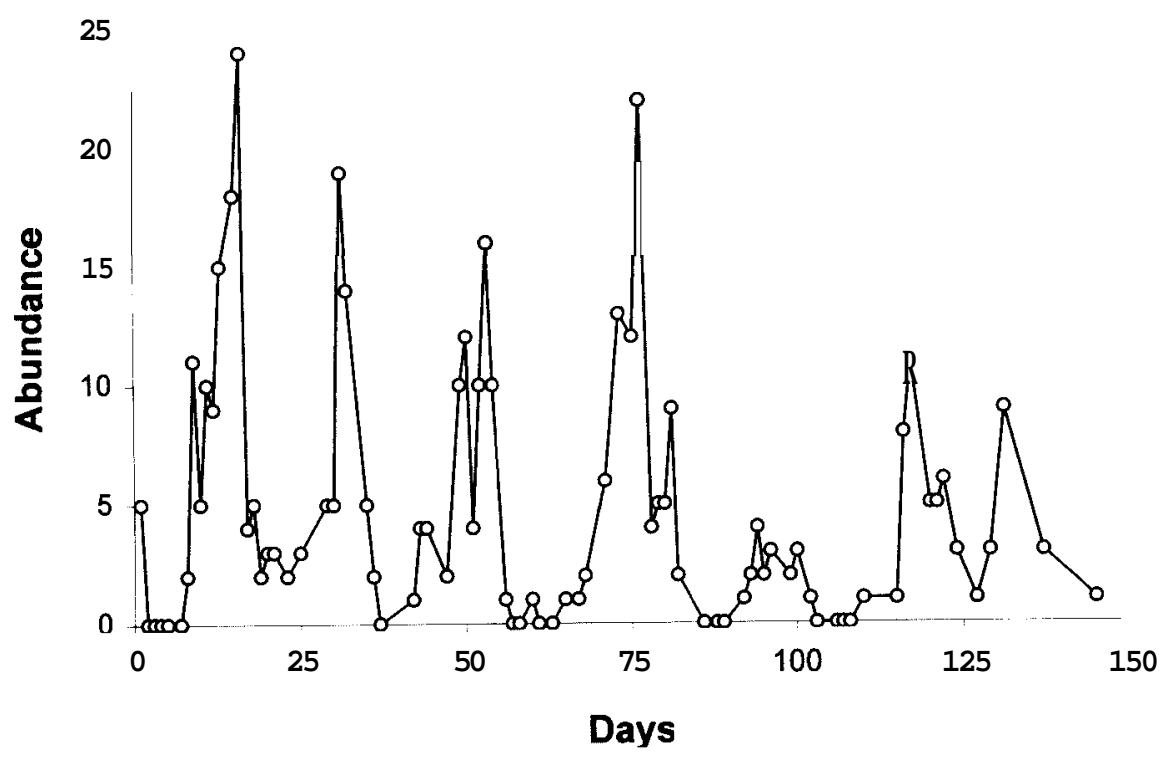

Figure 7. Abundance of the epilimnetic ciliate Strobilidium sp. in Priest Pot over a period of 145 days beginning 27 June 1988 . Abundances are per $5 \mathrm{ml}$. Whether or not this ciliate species is detected in a sample of this volume depends on the sampling date. The dynamic changes in population density are believed to be typical of many microbial eukaryote species and are the product of complex reciprocal interactions between physical, chemical and biological factors. Adapted from Finlay \& Esteban (1998b). Abundanciu del ciliado epilimnético Strobilidium sp. en Priest Pot a lo largo de un periodo de 145 dias a partir del 27 de Junio de 1988. Las ubundancias se indican para muestras de 5 ml. Que este ciliado sea o no detectado en una muestra de este volumen depende de la fecha de la muestra. La dinumica de los cambios en la densidad de la población se cree que son típicos de muchas especies de microbios eucariotas y son el resultado de interacciones reciprocas complejas entre factores físicos, quimicos y biológicos. Adaptado de Finlay y Esteban (1998b). 
CENSKY, E.J., K. HODGE, \& J. DUDLEY, 1998. Over-water dispersal of lizards due to hurricanes. Nature, 395: 556.

CHOI, J.W. \& F. PETERS, 1992. Effects of temperature on two psychrophilic ecoptypes of a heterotrophic nanoflagellate, Paraphysomonas imperforata. Appl. Env. Microbiol., 58: 593-599.

COLEMAN, A.W., A. SUAREZ, \& L.J. GOFF, 1994. Molecular delineation of species and syngens in volvocacean green algae (Chlorophyta). J. Phycol., 30: $80-90$.

CORLISS, J.O. 1999. Biodiversity and numbers of species of protists. In: Nature and Human Society: the Quest for a Sustainable World. Raven, P. \& Williams, T. (eds). National Academy Press, Washington D.C.

DARWIN, C. 1859. On the Origin of Species by Means of Natural Selection. London.

DRAGESCO, J. 1970. Cilies libres du Cameroun. Ann. Fac. Sci. Yaoundé (Hors série), $141 \mathrm{pp}$.

ESTEBAN, G.F., B.J. FINLAY, N. CHARUBHUN, \& B. CHARUBHUN. On the geographic distribution of Loxodes rex (Protozoa, Ciliophora) and other alleged endemic species of ciliates. J. Zool., 55:139-143.

ESTEBAN, G.F., B.J. FINLAY, J.L. OLMO, \& P.A. TYLER, 2000. Ciliated protozoa from a volcanic crater-lake in Victoria, Australia. J. Nat. Hist., 34: 159-189.

FELT, E.P. 1926. The physical basis of insect drift. Nature, 117: 754-755.

FENCHEL, T. 1987a. Ecology-Potentials and Limitations. Ecology Institute. $\boldsymbol{O}$. Kinne (ed). Oldendorf/ Luhe. 186pp.

FENCHEL, T. 1987b. Ecology of Protozoa. Science Tech, Madison, 197pp.

FENCHEL, T. 1993. There are more small than large species? Oikos, 68: 375-378.

FENCHEL, T., G.F. ESTEBAN, \& B.J. FINLAY, 1997. Local versus global diversity of microorganisms: cryptic diversity of ciliated protozoa. Oikos, 80: 220-225.

FINLAY, B.J. 2000. Protozoa. In: Encyclopedia of Biodiversity. S. A. Levin (ed). Academic Press, San Diego.

FINLAY, B.J., H.I.J. BLACK, S. BROWN, K.J. CLARKE, G.F. ESTEBAN, R.M. HINDLE, J.L. OLMO, A. ROLLETT, \& K. VICKERMAN, 2000. Estimating the growth potential of the soil protozoan community. Protist, 151: 69-80.

FINLAY, B.J. \& K.J. CLARKE, 1999a. Ubiquitous dispersal of microbial species. Nature, 400: 828.
FINLAY, B.J. K.J. \& CLARKE, 1999b. Apparent global ubiquity of species in the protist genus Paraphysomonas. Protist, 150: 419-430

FINLAY, B.J., J.O. CORLISS, G. ESTEBAN, \& T. FENCHEL, 1996a. Biodiversity at the microbial level: the number of free-living ciliates in the biosphere. Quart. Rev. Biol., 71: 221-237.

FINLAY, B.J. \& G.F. ESTEBAN, 1998a. Freshwater protozoa: biodiversity and ecological function. Biodic. Conserv., 7: 1163-1186.

FINLAY, B.J. \& G.F. ESTEBAN, 1998b. Planktonic ciliate species diversity as an integral component of ecosystem function in a freshwater pond. Protist, 149: 155-165.

FINLAY, B.J., G.F. ESTEBAN, \& T. FENCHEL, 1996b. Global diversity and body size. Nature, 383: 132-133.

FINLAY, B.J., G.F. ESTEBAN, \& T. FENCHEL, 1998. Protozoan diversity: converging estimates of the global number of free-living ciliates. Protist, 149: 29-37.

FINLAY, B.J., G.F. ESTEBAN, J.L. OLMO, \& P.A. TYLER, 1999. Global distribution of free-living microbial species. Ecography, 22: 138-144.

FINLAY, B.J. T. \& FENCHEL, 1999. Divergent perspectives on protist species richness. Protist, 150: 229-233.

FINLAY, B.J. \& S.C. MABERLY, 2000. Microbial Diversity in Priest Pot. Freshwater Biological Association, Ambleside. 73pp.

FINLAY, B.J., S.C. MABERLY, \& J.I. COOPER, 1997. Microbial diversity and ecosystem function. Oikos, 80: 209-213.

FINLAY, B.J., S.C. MABERLY, \& G. ESTEBAN, 1996c. Spectacular abundance of ciliates in anoxic pond water: contribution of symbiont photosynthesis to host respiratory oxygen requirements. FEMS Microbiol. Ecol., 20: 229-235.

GASTON, K.J. 1992. Regional numbers of insect and plant species. Funct. Ecol., 6: 243-247.

GISLEN, T. 1948. Aerial plankton and its conditions of life. Biol. Rev., 23: 109-126.

KUSCH, J. 1998. Local and temporal distribution of different genotypes of pond-dwelling Stentor coeruleus. Protist, 149: 147-154.

LARSEN, A. \& L.K. MEDLIN, 1997. Inter- and intraspecific genetic variation in twelve Prymnesium (Haptophyceae) clones. J. Phycol., 33: 1007 1015.

LAWTON, J.H. 1998. Small is beautiful, and very strange. Oikos, 81: 3-5. 
LEE, R.E. 1978. Formation of scales in Paraphysomonas vestita and the inhibition of growth by germanium oxide. J. Protozool., 25: 163-166.

LEE, C.C. \& T. FENCHEL, 1972. Studies on ciliates associated with sea ice from Antarctica. II. Temperature responses and tolerance in ciliates from Antarctic, temperate and tropical habitats. Arch. Protistenkd., 114: 237-244.

MARQUET, P.A. 2000. Invariants, scaling laws, and ecological complexity. Science, 289: 1487-1488.

MARSHALL, W.A. 1996. Biological particles over Antarctica. Nature, 383: 680.

NANNEY, D.L. 1999. When is a rose?: The kinds of tetrahymenas. In: Species: New Interdisciplinary Essays. R.W. Wilson (ed). MIT Press.

NANNEY, D.L., C. PARK, R. PREPARATA, \& E.M. SIMON, 1998. Comparison of sequence differences in a variable $23 \mathrm{~S}$ rRNA domain among sets of cryptic species of ciliated protozoa. J. Eukaryot. Microbiol., 45: 91-100.

OGDEN, C.G. \& R.H. HEDLEY, 1980. An Atlas of Freshwater Testate Amoebae. Oxford University Press. 222 pp.
PEREZ-UZ, B. 1995. Growth rate variability in geographically diverse clones of Uronema (Ciliophora: Scuticociliatida).FEMS Microbiol. Ecol., 16: 193-204.

PETERS, R.H. 1983. The ecological implications of body size. Cambridge University Press, 329pp.

ROBERTS, M.S. \& EM. COHAN, 1995. Recombination and migration rates in natural populations of Bacillus subtilis and Bacillus mojavensis. Evolution, 49: 1081-1094.

SCHMID, P.E., M. TOKESHI, \& J.M. SCHMIDARAYA, 2000. Relation between population density and body size in stream communities. Science, 289: $1557-1560$.

SHELDON, R.W., A. PRAKASH, \& W.H. SUTCLIFFE, 1972. The size distribution of particles in the ocean. Limnol. Oceanogr., 17:327-340.

TYLER, P.A. 1986. Endemism in freshwater algae. Hydrobiologia, 336: 127-135.

WRIGHT, A.-D. 1999. Analysis of intraspecific sequence variation among eight isolates of the rumen symbiont, Isotricha prostoma (Ciliophora), from two continents. J. Eukaryot. Microbiol., 46: 445-446. 